\title{
Pengembangan Sistem Informasi Sosial Ekonomi untuk Menunjang Perencanaan Wilayah Tingkat Provinsi (Uji Coba di Provinsi Lampung)
}

\author{
Diterima : 02 Juli 2012 \\ Disetujui : 31 Juli 2012
}

Nurjanah', Imam Buchori²

\begin{abstract}
Development activities demand land use and spatial planning which are supported by a geographically based physical and socio-economic information system. The availability of fast, accurate and current data has been a fundamental challenge in regional planning. Currently, data needed for urban and regional development planning has not been fully available at the basic data providing institution. Discrepancy of definitions between the data provider and user (the regional planners) are not uncommon. One solution is to establish a specific spatial information system containing the data needed by the planners. The study aims to develop a model of social-economic information system to support regional planning activity at the provincial level. The system contains demographic and economic data and information, which will be used in the regional planning process by using Arcview software. The sistem should assist regional planners by providing fast information in the spatial dimension. The study concluded that the now established system has given simplicity in work with added aesthetical value. The system helps both spatial and numerical analysis by integrating both data system, allowing policy makers and development actors to easily make a decision based on spatial dimension.
\end{abstract}

Key words: information system, development planning, socio-economic

\begin{abstract}
ABSTRAK
Kegiatan pembangunan menuntut perencanaan penggunaan lahan dan penataan ruang yang didukung sistem informasi fisik dan sosial ekonomis yang berbasis geografi. Ketersediaan data dan informasi yang cepat, akurat, dan terkini merupakan salah satu tantangan mendasar dalam membuat perencanaan wilayah. Saat ini data yang diperlukan dalam perencanaan pembangunan wilayah dan kota belum sepenuhnya tersedia pada institusi penyedia data dasar. Terkadang ada ketidaksesuaian definisi data antara institusi penyedia dengan penggunanya (para perencana wilayah). Salah satu solusi yang dapat diambil adalah membangun sistem informasi keruangan data yang diperlukan perencana yang belum terpenuhi oleh penyedia data. Studi ini bertujuan mengembangkan suatu model sistem informasi sosial ekonomi penunjang kegiatan perencanaan wilayah tingkat provinsi. Sistem tersebut berisi data dan informasi kependudukan dan ekonomi, yang akan digunakan dalam penyusunan perencanaan wilayah dengan menggunakan bantuan perangkat lunak Arcview. Sistem yang dihasilkan diharapkan dapat membantu perencana wilayah dengan memberikan informasi secara cepat dan berdimensi keruangan. Hasil studi ini menyimpulkan bahwa sistem informasi yang dibangun memberikan kemudahan bekerja dan memiliki nilai estetis. Sistem tersebut membantu kinerja analisis keruangan dan analisis numerik dengan jalan mengintegrasikan kedua sistem data tersebut, sehingga para pengambil kebijakan dan pelaku pembangunan dapat dengan mudah mengambil keputusan yang memiliki dimensi keruangan.
\end{abstract}

Kata kunci: sistem informasi, perencanaan wilayah, sosial ekonomi

\footnotetext{
${ }^{1}$ Staf Badan Pusat Statistik Provinsi Lampung

${ }^{2}$ Dosen Jurusan Perencanaan Wilayah dan Kota, Undip, Semarang, Jawa Tengah

Kontak Penulis : i.buchori@undip.ac.id
} 


\section{PENDAHULUAN}

Tuntutan kebutuhan data keruangan (spatial), baik untuk kehidupan manusia sehari-hari maupun tujuan-tujuan khusus makin banyak dan kompleks, karena kebutuhan data keruangan dan analisisnya tidak hanya dibutuhkan oleh ilmuwan kebumian saja. Pemerintah daerah memerlukan informasi tentang distribusi penggunaan lahan untuk perencanaan pengembangan tata ruangnya dan penentuan kebijaksanaan untuk pembangunan sarana dan fasilitas umum. Kegiatan pembangunan menuntut adanya perencanaan penggunaan sumber daya lahan dan penataan ruang yang didukung oleh informasi fisik dan sosial ekonomis yang berbasis geografis. Salah satu tantangan yang paling mendasar dalam membuat perencanaan wilayah adalah tersedianya data dan informasi yang akurat, presisi, tepat waktu, dan dibutuhkan.

Informasi merupakan salah satu kunci keberhasilan dari sistem informasi perencanaan. Saat ini informasi juga telah menjadi kebutuhan mutlak dalam penyelenggaraan pembangunan. Kebutuhan terhadap data dan informasi secara cepat dan akurat menuntut adanya suatu sistem informasi yang mampu mewadahinya. Kemajuan teknologi telah memungkinkan terjadinya transfer informasi secara lebih efisien dan global. Salah satu sistem informasi yang dapat digunakan sebagai alat bantu (tools) dalam menyimpan, memanipulasi, menganalisis, dan menampilkan kembali kondisi-kondisi alam dengan bantuan data atribut dan spasial adalah Sistem Informasi Geografis (SIG) (Aronoff, 1989). Banyak sekali aplikasi yang dapat ditangani oleh SIG, sebagai contoh aplikasi SIG di bidang perencanaan seperti perencanaan pemukiman transmigrasi, perencanaan tata ruang wilayah, perencanaan kota, perencanaan lokasi dan relokasi industri, pasar, pemukiman dan sebagainya (Huisman, 1986). Contoh lain adalah aplikasi SIG di bidang kependudukan atau demografi seperti penyusunan data pokok, penyediaan informasi kependudukan/sensus dan sosial ekonomi, sistem informasi untuk pemilihan umum dan sebagainya (Agung, 1994; Han, 1990; Harris, 1993; Kusdiatmono, 2000; Sulaiman, 2000).

Dengan kelebihan-kelebihan yang dimiliki SIG, maka perencanaan dan pengembangan wilayah dapat menggunakan aplikasi yang dimilikinya. Dengan sistem ini dapat dilakukan berbagai analisis keruangan (spatial analysis) dan analisis data-data numerik (numerical analysis) secara mudah. Sistem ini juga mampu mengintegrasikan data keruangan dengan data numerik sehingga para pengambil keputusan dan para pelaku pembangunan dapat dengan mudah mengambil suatu keputusan yang berdimensi keruangan.

Berdasarkan latar belakang tersebut maka pengembangan sistem informasi yang mampu menyediakan data/informasi yang terkini (up to date) sangat diperlukan keberadaannya. Untuk itu, studi ini bertujuan untuk mengembangkan suatu sistem informasi untuk menunjang kegiatan perencanaan wilayah tingkat provinsi khususnya dalam memberikan data dan informasi secara cepat, akurat, dan terkini. Berdasarkan tujuan tersebut, sasaran studi ini adalah sebagai berikut:

1. Mengidentifikasi sistem informasi untuk mendukung kegiatan perencanaan wilayah.

2. Mengembangkan konsep sistem informasi yang terstruktur dan menyeluruh khususnya sistem informasi sosial ekonomi untuk mendukung kegiatan perencanaan wilayah.

3. Mengaplikasikan konsep di atas ke dalam sistem informasi berbasis SIG yang bersifat operatif dan user friendly.

4. Melakukan evaluasi model sistem informasi sosial ekonomi dan melakukan perbaikan agar diperoleh sistem informasi yang sesuai dengan kebutuhan perencanaan wilayah. 
Ujicoba sistem informasi adalah di Provinsi Lampung, dengan pertimbangan sebagian besar data yang dibutuhkan telah tersedia.

\section{METODE PENGEMBANGAN SISTEM INFORMASI}

\section{Konsep Sistem Informasi}

Sistem informasi yang dibangun adalah sistem informasi sosial ekonomi yang berisi data dan informasi mengenai kependudukan dan ekonomi yang digunakan dalam menyusun perencanaan wilayah tingkat provinsi dengan menggunakan bantuan perangkat lunak (software) Arcview. Pemilihan perangkat lunak mengacu pada hasil penelitian terdahulu yang menunjukkan bahwa perangkat lunak tersebut merupakan perangkat lunak yang telah banyak dipakai secara luas oleh berbagai instansi, baik pemerintah maupun swasta (Buchori, 2005).

Analisis sosial ekonomi yang dimaksud adalah analisis-analisis sektoral sebagaimana yang biasa dilakukan dalam penyusunan Rencana Tata Ruang Wilayah Provinsi (lihat Oppenheim, 1980). Data yang digunakan untuk analisis sektor sosial adalah jumlah penduduk, penduduk menurut mata pencaharian, penduduk menurut tingkat pendidikan, penduduk menurut struktur usia, penduduk menurut jenis kelamin, angka kelahiran dan angka kematian, tingkat buta huruf, dan jumlah pengangguran. Sedangkan untuk analisis sektor ekonomi menggunakan data PDRB dan income per capita. Selain data dasar tersebut, dilakukan juga analisis dengan metode kuantitatif yang biasa digunakan dalam perencanaan wilayah yaitu Location Quotient, Analisis Shift Share, Indeks Williamson, analisis penentuan pusat-pusat pelayanan, dan juga analisis statistik berupa indikator-indikator sosial.

Teknik dan metode desain sistem informasi sosial ekonomi yang meliputi kegiatan perancangan dan pembuatan software dan database sistem informasi, yang terdiri dari kegiatan identifikasi kebutuhan informasi, identifikasi kemampuan dukungan data BPS, perumusan konsep perancangan serta perancangan kerangka dan proses kerja data base management system (DBMS), perancangan software yang meliputi juga rancangan user interface sederhana.

\section{Tahapan Pengembangan Sistem Informasi}

Sebagai tahap awal dilakukan kegiatan perancangan Sistem Informasi Sosial Ekonomi. Pertama yang harus dilakukan adalah identifikasi terhadap kebutuhan analisis sosial ekonomi. Selanjutnya, terhadap hasil identifikasi tersebut dilakukan beberapa kajian sehingga diperoleh alur informasi, mulai dari kebutuhan data, analisis, sampai dengan keluaran/hasil analisis. Selain itu, dari identifikasi kebutuhan analisis sosial ekonomi dapat dirumuskan sistem user interface yang diperlukan untuk mempermudah dalam mengoperasikan sistem tersebut. Sebelum sistem informasi sosial ekonomi digunakan, terlebih dahulu dilakukan validasi dan evaluasi. Selanjutnya kebutuhan analisis sosial ekonomi yang meliputi analisis sosial kependudukan dan analisis ekonomi dilakukan model kerja sektoral. Model kerja sektoral adalah semacam kerangka pikir sektoral yang menggambarkan serangkaian proses analisis sektoral yang meliputi data input, proses analisis, dan output analisis.

Dari model kerja sektoral tersebut kemudian diturunkan menjadi model informasi sektoral. Model informasi sektoral adalah semacam diagram alir yang menggambarkan proses analisis secara lebih teknis. Masing-masing kotak informasi berisi peta yang dipergunakan. Peta tersebut dapat berupa peta informasi dasar ataupun peta bentukan baru hasil dari suatu analisis. Informasi yang lain adalah kebutuhan atribut. Atribut ini juga dapat berupa data 
atribut dasar atau data atribut hasil suatu proses analisis. Dalam kotak informasi juga dapat dilihat apakah tema informasi merupakan informasi dasar, atau informasi yang terbentuk dari suatu proses analisis. Dari model informasi sektoral dapat juga dilihat kebutuhan untuk perancangan user interface.

Pengumpulan data dilakukan secara sekunder berupa data yang telah ada di BPS Provinsi Lampung. Jenis data yang digunakan dalam penelitian ini ada dua macam yaitu (1) jenis data yang merepresentasikan aspek-aspek keruangan dari fenomena yang bersangkutan, sering disebut data spasial, (2) jenis data yang merepresentasikan aspek-aspek deskriptif dari fenomena yang dimodelkan, sering disebut data non-spasial atau data atribut. Data spasial dalam penelitian ini berupa peta administrasi, peta ini memuat gambaran wilayah administrasi Provinsi Lampung yang dirinci dengan batas kabupaten dan wilayah administrasi kabupaten/kota yang dirinci dengan batas kecamatan dalam bentuk peta indeks. Data atribut dalam penelitian ini berupa data statistik, yang diperoleh dari BPS Provinsi Lampung. Selain data dari BPS terdapat juga data rekaan karena data tersebut tidak atau belum tersedia di dinas yang terkait. Data rekaan ini digunakan agar sistem dapat berjalan dan diharapkan dengan adanya penelitian ini dinas terkait dapat menyediakan data yang digunakan dalam perencanaan. Evaluasi sistem dilakukan dalam bentuk seminar dengan mengundang Bappeda Provinsi serta instansi terkait. Hasil evaluasi ini selanjutnya digunakan untuk memperbaiki aplikasi sistem yang sesuai untuk perencanaan wilayah.

\section{SISTEM INFORMASI SOSIAL EKONOMI (SISE)}

Aplikasi Sistem Informasi Sosial Ekonomi (SISE) merupakan suatu program komputer yang interaktif dan mudah digunakan. Aplikasi ini menampilkan data dan informasi sosial ekonomi dalam bentuk peta yang diberi gradasi warna menurut kondisi tertentu, analisis-analisis sosial ekonomi yang meliputi proyeksi penduduk, indikator-indikator sosial, analisis Location Quotient, Shift Share, Indeks Williamson, Scalogram, analisis titik henti, dan indeks gravitasi. Aplikasi ini dilengkapi dengan fasilitas pembesaran, pengecilan, dan penggeseran peta. Peta yang digunakan dalam aplikasi ini adalah peta sketsa hasil pengumpulan Badan Pusat Statistik. Untuk memulai penggunaan program aplikasi SISE dengan cara memanggil sistem dari explore atau dengan klik ganda pada shortcut SISE di desktop. Secara garis besar, tampilan program aplikasi SISE terbagi atas 2 bagian yaitu Gambaran Umum dan Menu Utama.

\section{Tampilan Aplikasi}

Tampilan gambaran umum seperti pada Gambar 1 muncul pada saat program aplikasi sistem dimulai. Komponen-komponen yang terdapat pada Gambaran Umum adalah View, Menu Utama, Menu Bar, Button Bar, dan Tool Bar dengan penjelasan sebagai berikut.

1. View, untuk menampilkan peta sesuai dengan Menu Utama yang dipilih.

2. Menu Bar, merupakan cara lain untuk akses ke tema-tema peta yang terdiri dari Indikator Sosial, Perhitungan PDRB, dan Data Ekonomi.

3. Button Bar, jajaran tombol di mana setiap tombol mempunyai fungsi untuk akses ke fasilitas tertentu. Tombol simpan untuk menyimpan project, tombol Gambar Penuh berfungsi untuk menampilkan seluruh wilayah yang ada di peta setelah dilakukan proses pembesaran atau perkecilan.

4. Tool Bar, jajaran tombol di mana setiap tombol mempunyai fungsi untuk akses ke fasilitas tertentu.

Tombol Perbesar, berfungsi untuk memperbesar tampilan peta. Klik tombol ini, kemudian pada View, wilayah yang ingin diperbesar diberi kotak dengan cara klik dan tahan di titik 
yang akan dijadikan sebagai sudut kiri atas kotak, lalu geser ke arah kanan bawah sampai terbentuk kotak yang diinginkan, baru dilepas.

Tombol Perkecil, berfungsi untuk memperkecil tampilan peta. Klik tombol ini, kemudian pada View, klik di bagian peta yang ingin diperkecil.

Tombol Geser, berfungsi menggeser gambar peta ke arah kiri, kanan, atas, atau bawah. Klik tombol ini, kemudian pada peta di View, klik, tahan dan geser ke arah yang diinginkan. Lepas setelah posisi peta sesuai dengan keinginan.

Tombol Terhubung ke Rumus, berfungsi untuk menampilkan rumus dan kegunaan dari indikator. Klik tombol ini, kemudian arahkan pointer ke point tertentu dan klik pada point tersebut.

Tombol Identitas data, berfungsi untuk menampilkan identitas data pada wilayah yang dipilih.

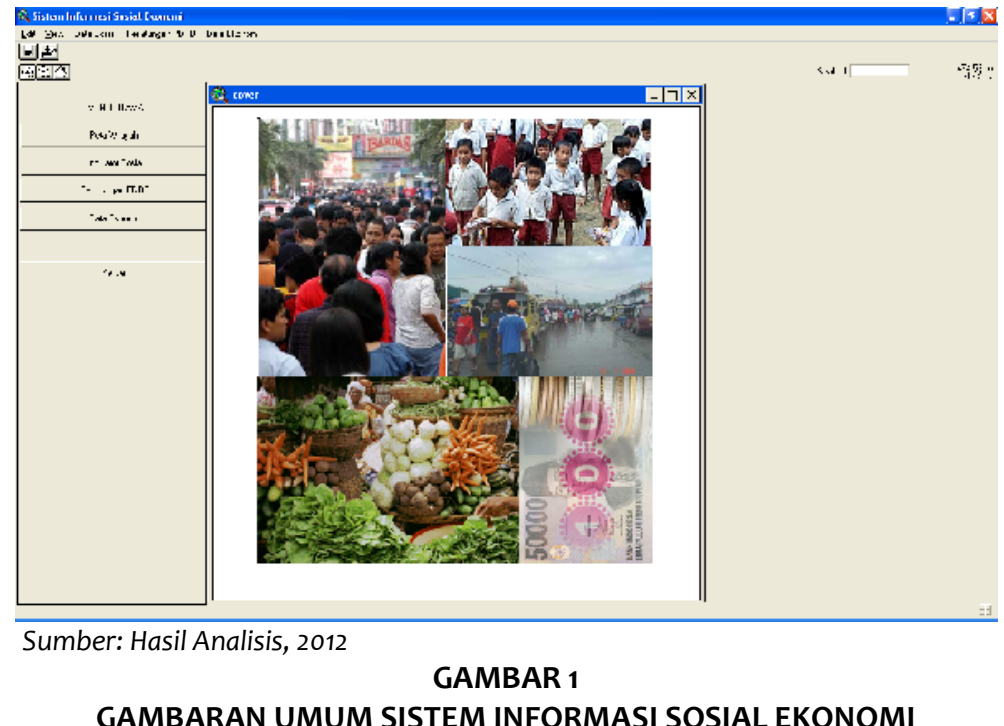

Menu Utama, terdiri dari:

a. Peta Wilayah, untuk memilih cakupan dan menampilkan peta wilayah pada View. Cakupan wilayah yang dapat dipilih adalah provinsi menurut kabupaten/kota dan kabupaten/kota menurut kecamatan. Untuk memilih cakupan dan menampilkan peta wilayah provinsi/kabupaten/kota, klik pada nama provinsi/kabupaten/kota yang ingin ditampilkan. Sebagai contoh, jika pada Peta Wilayah ditampilan Gambar 1 diklik maka akan muncul tampilan seperti pada Gambar 2. Jika ingin melihat tampilan kabupaten/kota menurut kecamatan, maka apabila diklik kabupaten maka akan muncul tampilan seperti pada Gambar 3 dan apabila diklik Lampung Barat maka akan muncul tampilan seperti pada Gambar 4. 

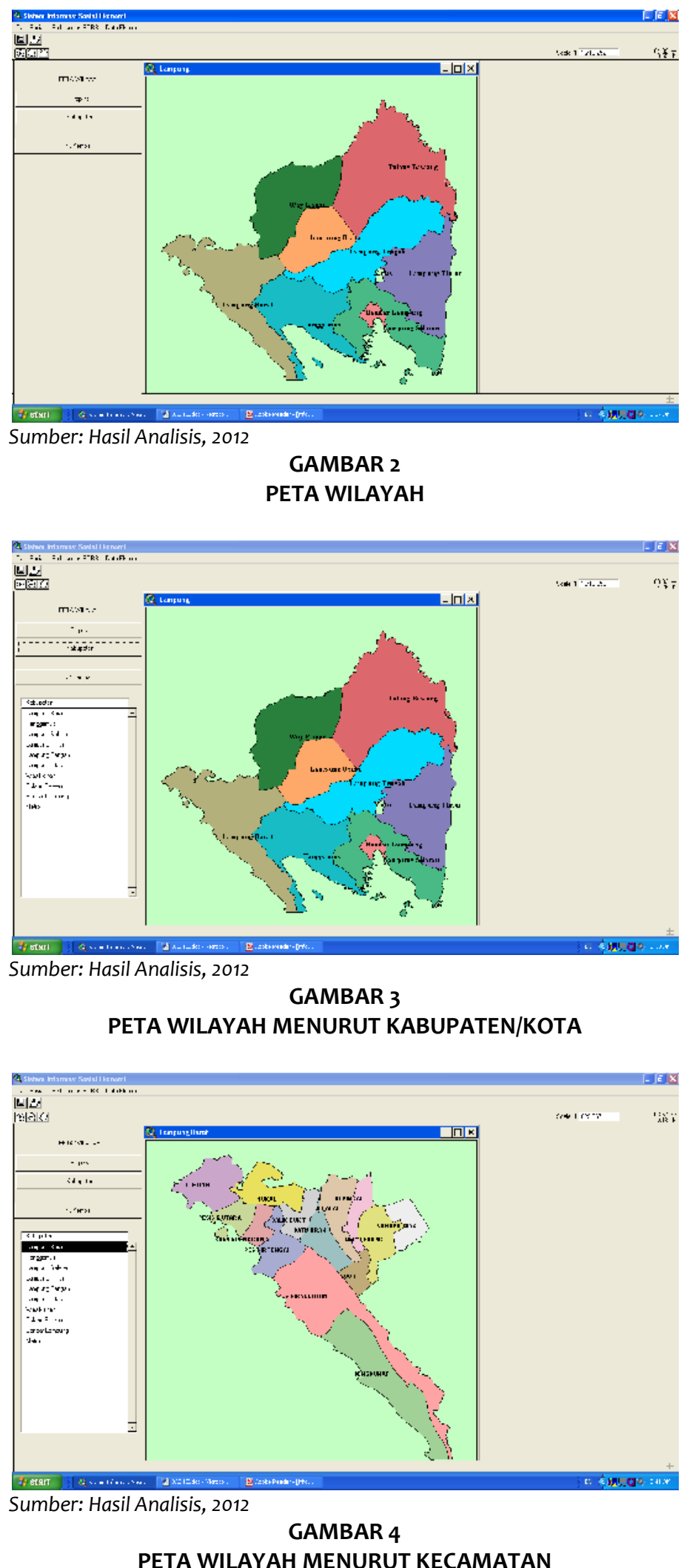


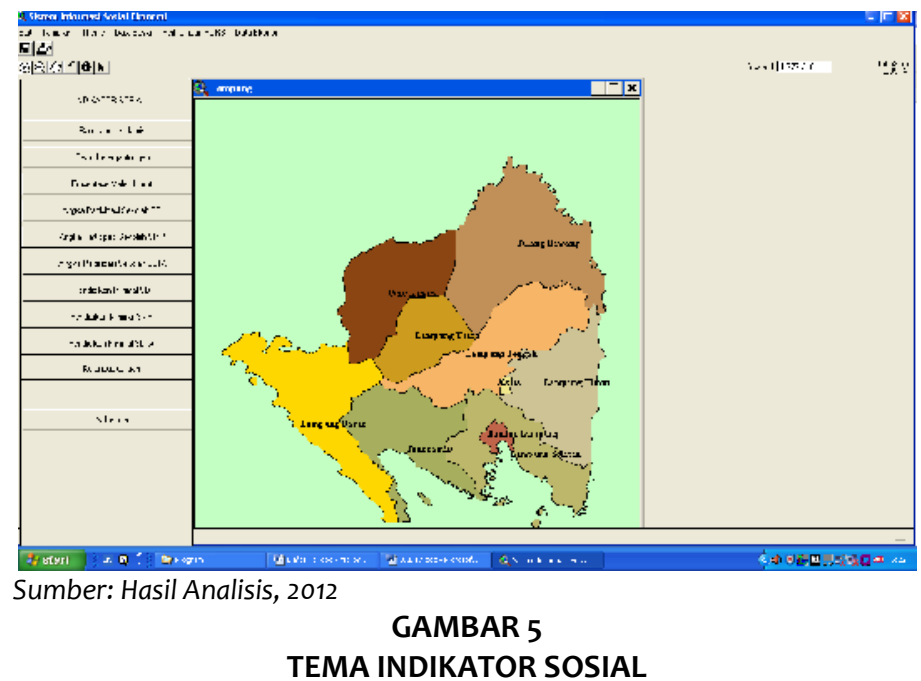

b. Indikator Sosial, untuk memilih tema peta sosial yang ingin ditampilkan pada View. Tematema peta sosial yang dapat dipilih adalah Rasio Penduduk Menurut Jenis Kelamin, Rasio Ketergantungan, Proyeksi Penduduk, Jumlah Melek Huruf, Angka Partisipasi Sekolah SD, Angka Partisipasi SMP, Angka Partisipasi SLTA, Pendidikan Minimal SD, Pendidikan Minimal SMP, Pendidikan Minimal SLTA, Ketenagakerjaan (lihat Gambar 5).

c. Perhitungan PDRB, untuk memilih tema peta perhitungan PDRB yang ingin ditampilkan pada View. Tema-tema peta perhitungan PDRB yang dapat dipilih adalah Pertanian, Pertambangan dan Penggalian, Industri Pengolahan, Listrik, Gas dan Air Minum, Bangunan, Perdagangan, Hotel dan Restoran, Angkutan dan Komunikasi, Keuangan, Persewaan dan Jasa Perusahaan serta Jasa-jasa. Untuk memilih sub tema dapat dilihat pada menu bar perhitungan PDRB (lihat Gambar 6).

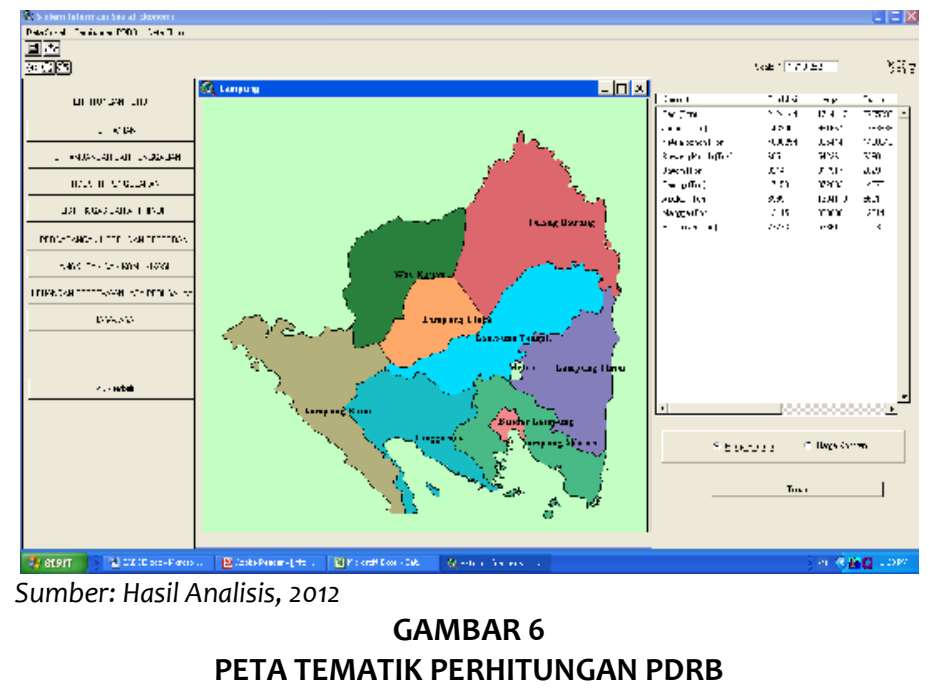

d. Data Ekonomi, untuk memilih tema peta Data Ekonomi yang ingin ditampilkan pada View. Tema-tema peta Data Ekonomi yang dapat dipilih adalah PDRB Berlaku, PDRB Konstan Income Perkapita, Laju Pertumbuhan Ekonomi 2005, Regional Aggregate Shift Share, Propostional Shift Share, Differential Shift Share, Location Quotient, Fasilitas Sosial Ekonomi 
(fasilitas sosial ekonomi setiap kecamatan, Scalogram Guttman, Indeks Sentralitas Marshall) (lihat Gambar 7).

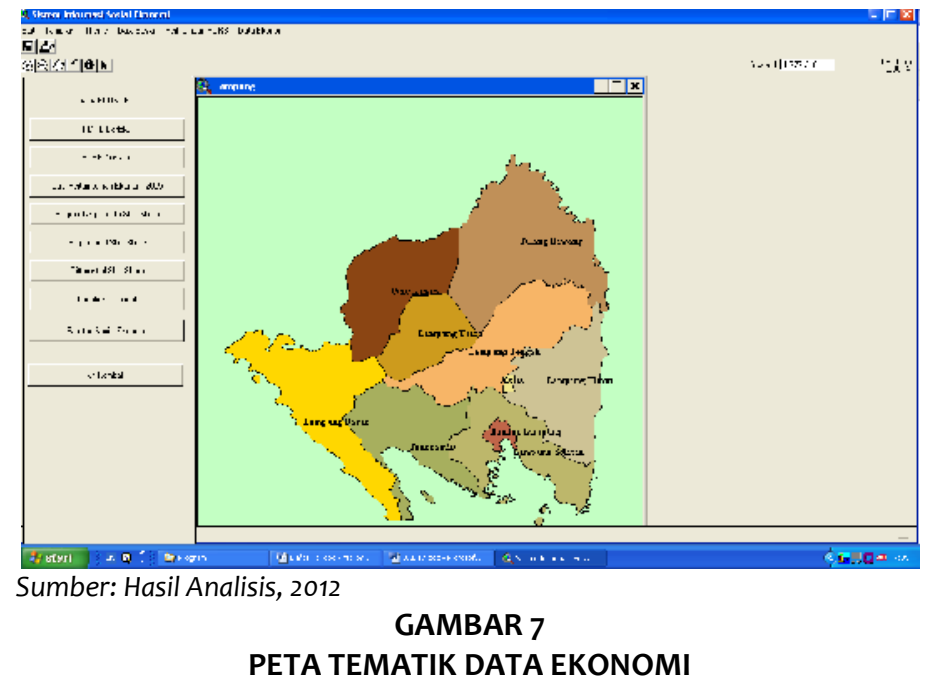

e. Keluar, jika tombol ini diklik maka akan keluar dari sistem.

\section{Menyunting Data}

Data yang tersaji dalam sistem ini dapat diubah atau ditambah sesuai dengan kebutuhan karena perencanaan merupakan suatu proses sehingga didalamnya memuat dimensi waktu, sehingga data yang ada dalam sistem inipun harus diusahakan untuk terus dikembangkan sesuai dengan kondisi dan kebutuhan. Menyunting data dapat dilakukan dengan klik pada ikon tables pada project window maka disebelahnya akan muncul sederetan daftar tabel yang sudah ada. Pada daftar tabel, pilih salah satu tabel lalu klik 2 kali (atau tekan tombol open) maka jendela tampilan akan muncul. Editing terhadap sebuah tabel mengharuskan tabel tersebut dalam keadaan siap edit. Jika tabel belum aktif, maka aktifkan terlebih dahulu dengan memilih Start Editing dari menu Table. Klik ikon Edit dari toolbar, pilih record yang akan diedit. Setelah tabel selesai diedit, kemudian pilih Stop Editing dari menu Table lalu klik Yes untuk penyimpanan data dan mengakhiri pengeditan.

\section{Pemanfaatan SISE dalam Perencanaan Wilayah dan Kota}

Dalam proses perencanaan wilayah dan kota memerlukan analisis-analisis di berbagai sektor. Analisis ini digunakan mulai untuk memahami, mendiskripsikan, sampai pada memberikan bahan pertimbangan dalam pengambilan keputusan dalam proses perencanaannya. Terkait dengan sektor sosial analisis digunakan untuk memahami aspek-aspek kependudukan seperti struktur penduduk, kualitas sumber daya manusia, karakteristik ketenagakerjaan dan sebagainya. Sedangkan untuk sektor ekonomi analisis digunakan untuk memperoleh pengetahuan mengenai karakteristik perekonomian dengan mengidentifikasi sektor-sektor unggulan, penentuan pusat-pusat pelayanan, pertumbuhan ekonomi dan sebagainya.

Dengan hasil perancangan SISE ini merupakan upaya untuk mengkombinasikan data dan informasi sosial ekonomi ke dalam bentuk peta sehingga memberikan kemudahan bagi penggunanya karena menghasilkan informasi secara cepat dan berdimensi keruangan. Dengan bantuan sistem informasi ini diharapkan dapat membantu dalam proses analisis sektor- sektor dalam perencanaan wilayah dan kota, khususnya sektor sosial dan ekonomi. Dengan kemampuan kemudahan memperbarui data (updating data) dengan memberikan pemahaman 
yang relatif lebih mudah maka akan memberikan manfaat dalam suatu proses pengambilan keputusan dalam proses perencanaan wilayah dan kota.

Sistem dirancang untuk memenuhi kebutuhan analisis sektor ekonomi dan sosial, tetapi dalam kenyataannya ada beberapa hal yang menjadikan kelemahan sistem ini. Pertama, ketidakmampuan untuk melakukan perhitungan proyeksi penduduk. Hal ini disebabkan karena memang tidak tersedia sebagian data penduduk seperti mobilitas penduduk (migrasi masuk dan migrasi keluar), jumlah kelahiran, dan jumlah kematian penduduk, selain itu juga karena keterbatasan fasilitas/tools yang dimiliki oleh Software Arcview. Kedua, sistem ini dibangun berdasarkan pada analisis sektoral yang akan dilakukan sehingga dapat diketahui data dasarnya dengan cepat, akan tetapi menjadi kurang efektif karena menyebabkan terdapat database yang harus di-entry ulang. Ketiga, bila dikaitkan dengan Kepmen PU Nomor:327/KPTS/M/2002 tentang Penetapan Enam Pedoman Bidang Penataan Ruang yang memuat aspek/sektor analisis yang diperlukan dalam sebuah perencanaan wilayah, lebih khusus pada sektor sosial ekonomi, maka hasil perancangan sistem informasi ini masih belum bisa memenuhi seluruh aspek-aspek yang akan dianalisis. Hal ini dikarenakan perancangan sistem informasi ini hanya merupakan model yang memungkinkan untuk dikembangkan lebih lanjut. Beberapa data yang tidak menjadi lingkup materi bahasan perancangan sistem informasi ini antara lain adalah kepadatan penduduk, pertumbuhan penduduk, serta jumlah dan besar investasi pemerintah dan swasta.

\section{Peluang Pengembangan SISE}

Tuntutan kajian perencanaan wilayah yang harus mampu menganalisis potensi yang ada pada unit spasial lebih yaitu kecil desa/kelurahan memberikan peluang untuk mengembangkan lebih lanjut sistem informasi ini. Data dasar yang berbasis pada unit spasial terkecil di lingkup desa/kelurahan telah tersedia dalam Data Potensi Desa (PODES). PODES menyediakan data yang menggambarkan potensi/keadaan pembangunan di desa/kelurahan yang meliputi keadaan sosial, ekonomi, sarana, dan prasarana. Pada dasarnya PODES bertujuan untuk berbagai keperluan khususnya yang berkaitan dengan kebutuhan perencanaan regional (spasial) di setiap daerah. Selain itu, PODES juga menyediakan informasi bagi keperluan penentuan dan updating klasifikasi desa urban dan rural serta desa tertinggal dan tidak tertinggal disamping menyediakan data pokok bagi penyusunan statistik wilayah kecil (small area statistics).

Dengan adanya peluang tersebut, maka di masa mendatang sangat dimungkinkan untuk mengembangkan sistem informasi ini yang berbasis pada unit spasial terkecil tersebut. Sistem yang mengkombinasikan data dan informasi sosial ekonomi ke dalam bentuk peta tematik diharapkan mampu memberikan 'keleluasaan' analisis pada unit desa/kelurahan. Salah satu peta tematik yang bisa dibangun melalui data PODES adalah penentuan sistem perkotaanpedesaan. Dengan diketahuinya sistem perkotaan-pedesaan atas unit spasial desa/kelurahan ini sangat berguna dalam kajian perencanaan wilayah pada skala yang lebih kecil/sempit. Secara konsepsual penentuan sistem perkotaan-pedesaan dengan menggunakan data PODES dapat dibangun melalui tahapan sebagai berikut:

- Dari data PODES dengan menggunakan Pedoman Sistem Skoring Kriteria PerkotaanPerdesaan yang telah disusun.

- Status desa/kelurahan atas tiap-tiap variabel mempunyai nilai (skor) yang spesifik, misalkan untuk desa $\mathrm{x}$ dengan kepadatan penduduk $=1500 \mathrm{jiwa} / \mathrm{km}^{2}$ maka mempunyai skor $=3$, demikian juga seterusnya untuk tiap-tiap variabel. 
- Dari penjumlahan nilai (skor) atas variabel-variabel tersebut di atas akan diperoleh nilai total skor.

- Klasifikasi desa/kelurahan ditentukan atas nilai total skor, jika nilai total skor lebih $\geq 10$ maka termasuk klasifikasi perkotaan (urban). Demikian juga bila nilai total skor < 10 maka termasuk klasifikasi perdesaan (rural).

- Untuk klasifikasi perkotaan (urban) akan dilakukan kajian lebih lanjut dengan menentukan besarannya. Besaran perkotaan ditetapkan sebagai small urban, middle urban, dan large urban.

- Untuk penentuan besarannya, akan diuji dengan menggunakan variabel ketersediaan fasilitas lainnya dan persentase lahan bangunan selain untuk perumahan.

- Dengan menggunakan kriteria yang ada pada akhirnya bisa ditentukan status kotanya, apakah masuk small, middle, atau large urban.

Penentuan sistem perkotaan-perdesaan yang berbasiskan data PODES pada tataran lebih dalam bisa dibandingkan dengan analisis lain, seperti Analisis Skalogram Guttman dan atau Indeks Sentralitas Marshall. Hasil perbandingan ini tentunya memerlukan pembahasan yang lebih mendalam dan komprehensif bilamana terdapat hasil yang tidak ekivalen/bias, misalnya dari hasil pengamatan lapangan/observasi visual, histori (asal mula) kota-kota dimaksud atau metode lainnya. Pengetahuan terhadap hirarki kota yang berbasis pada unit spasial desa/kelurahan memberikan manfaat dalam penentuan pusat-pusat wilayah pembangunan regional yang menjadi inti fungsi perencanaan wilayah.

\section{KESIMPULAN}

Hasil akhir studi ini adalah sistem informasi dengan mengkombinasikan data dan informasi sosial ekonomi ke dalam bentuk peta sehingga memberikan kemudahan bagi penggunanya karena menghasilkan informasi secara cepat dan berdimensi keruangan. Perancangan sistem informasi ini merupakan model yang dimungkinkan akan berkembang lebih lanjut, untuk itu hanya memuat sebagian dari sektor-sektor yang harus dianalisis dalam sebuah perencanaan wilayah. Dari penelitian yang menghasilkan rancangan Sistem Informasi Sosial Ekonomi (SISE) ini terdapat beberapa hal yang dapat ditarik kesimpulan dari penelitian ini yaitu:

1. Sistem yang operatif memungkinkan pengguna dapat mengetahui rumus dan kegunaan dari indikator, sehingga memahami fungsi dari masing-masing indikator tersebut.

2. Sistem yang mengkombinasikan data dan informasi sosial dan ekonomi ke dalam bentuk peta menghasilkan tampilan yang menarik dan kompak sehingga memberikan kemudahan praktis bagi pengguna dalam memahami makna dari indikator yang ditampilkan.

3. Hasil analisis sistem dapat menampilkan ke dalam satuan/unit administrasi setingkat kabupaten/kota sehingga memungkinkan diperoleh informasi mengenai karakteristik perekonomian dari hasil identifikasi sektor-sektor unggulan serta pertumbuhan ekonomi antar kabupaten/kota di wilayah provinsi.

4. Sistem ini mendasarkan pada analisis yang akan dilakukan dengan maksud untuk memudahkan pengguna menampilkan indikator yang diperlukan dalam perencanaan wilayah, sehingga dapat diketahui data dasarnya dengan cepat, tetapi desain sistem ini menyebabkan kurang efektif karena masih terdapat database yang harus di-entry ulang.

5. Desain sistem belum memungkinkan untuk melakukan perhitungan proyeksi penduduk yang berdasar pada data mobilitas, jumlah kelahiran, dan jumlah kematian penduduk karena masih memerlukan tools lain yang membantu dalam perhitungan notasi matriksnya. 


\section{DAFTAR PUSTAKA}

Agung, A. A Gde. 1994. “Mendefinisikan Kebutuhan GIS untuk Perencanaan Wilayah dan Kota”. Jurnal Perencanaan Wilayah dan Kota. Edisi Khusus Februari 1994.

Aronoff, Stan. 1989. Geographic Information Systems: A Management Perspective. Ottawa, Canada: WDL Publications.

Badan Pusat Statistik. 2005. Indikator Statistik Bidang Sosial menurut Jenis dan Penggunaannya. Subdirektoral Klasifikasi dan Pembakuan Statistik Direktorat Metodologi Statistik. Jakarta.

Buchori, I. 2005. Developing Spatial Information System for Regional Planning in Indonsia, a Case Study of the Rembang Regency. Vechta: HS Vechta Verlag.

Han, Sang Yun dan Kim, Tschangho John. 1989. "Intelligent Urban Information Systems: Review and Prospects". Journal of The American Planning Association. Vol. 55, No. 3.

Harris, Britton dan Batty, Michael. 1993. "Locational Models, Geographic Information and Planning Support Systems". Journal of Planning Education and Research. Vol. 12: 184-198. Association of Collegiate Schools of Planning.

Huisman, Henk. 1986. Regional and Rural Development Planning Series. Yogyakarta: Faculty of Geography Gadjah Mada University.

Kusdiatmono, Wien. 2000. Analisa Rasio Jenis Kelamin. In-Country Training Improvement of the 2000 Population Census. BPS-JICA.

Oppenheim, Norbert. 1980. Applied Models in urban and Regional Analysis. New Jersey: Prentice Hall Inc. Englewood Cliffs.

Sulaiman, Dudy. 2000. Analysis for Small Area Statistics. In-Country Training for Tabulation, Analysis and Dissemination of the 2000 Population Census. BPS-JICA. 